\title{
Building a typology of cropping practices from comparison with a technical reference: first step for a relevant cropping system redesigning process - results for tropical citrus production
}

\author{
Fabrice Le Bellec ${ }^{1 *}$, Philippe CATtAN ${ }^{2}$, Muriel Bonin ${ }^{3}$, Amélie RaJAud ${ }^{4}$
}

${ }^{1}$ CIRAD-Persyst, UPR

HortSys, TA B-103 / PS4,

Blvd. de la Lironde,

34398 Montpellier Cedex 5,

France

lebellec@cirad.fr

2 CIRAD-Persyst, UPR

Systèmes bananes et ananas,

Stn. Neufchâteau,

Sainte-Marie,

97130 Capesterre-Belle-Eau, France

${ }^{3}$ CIRAD-ES, UMR TETIS,

TA C-91 / F-Campus Int.

Baillarguet, 34398 Montpellier

Cedex 5, France

${ }^{4}$ CIRAD-Persyst, UPR

HortSys, Stn. Bassin-Plat,

BP 180, 97455 Saint-Pierre,

France

* Correspondence and reprints

Received 13 November 2010 Accepted 11 February 2011

Fruits, 2011, vol. 66, p. 143-159 (C) 2011 Cirad/EDP Sciences All rights reserved DOI: $10.1051 /$ fruits/2011026 www.fruits-journal.org

RESUMEN ESPAÑOL, p. 159

\begin{abstract}
Building a typology of cropping practices from comparison with a technical reference: first step for a relevant cropping system redesigning process - results for tropical citrus production.
\end{abstract}

\begin{abstract}
Introduction. Farm typologies and cropping practice typologies generally aim at seeking determinants of existing crop management strategies. They constitute the first step for setting improvement goals for cropping systems. Though there are a host of farm typology methods, few deal specifically with farmers' practices, and even fewer investigate the correlations between practices. We propose here a framework for analysing the determinants of crop management, based on a vision of a crop management sequence condensed into logical combinations of cropping techniques. Materials and methods. This analytical framework was applied to the case of Guadeloupian citrus production, using a representative sample of 41 producers. Three stages were necessary to implement our analytical framework. At stage 1, logical and ordered combinations of cropping practices (CCPs), constitutive of observed as well as reference crop managements (RCMs), were identified through expert analysis. Based on measurements of deviations between farmers' CCPs and RCMs' CCPs, a typology of cropping practices was next built. At stage 2, the performances of farmers' crop managements were evaluated using relevant indicators. Finally, at stage 3 , constraints - either related to the environment or to the whole farm management - that determined producers' cropping practices were identified for making, with the stakeholders, proposals for further technical improvements. Results. Crop management sequences were condensed into five CCPs. A technical profile was then determined for every producer, before a multiple correspondence factorial analysis was run. It identified two groups of producers with contrasting technical profiles. The collective analysis of these results pointed out "weed management" as a major constraint on the cropping systems, revealing that the RCM was inadequate in a context of impossible mechanisation. Discussion. Restructuring complex sequences of cropping techniques into five logical combinations of techniques enabled the comparison with a reference crop management. The cropping systems' constraints and the objectives for further improvements were then set up collectively by the farmers and social stakeholders, along with the researchers. This analysis constitutes the first stage of a process of redesigning cropping systems, and its result provides a sound basis for a participatory approach.
\end{abstract}

France (Guadeloupe) / Citrus / systems analysis / cropping systems / cultivation / weed control / expert systems / participation / farmers

Construction d'une typologie des pratiques culturales par comparaison avec une référence technique: première étape de re-conception d'un système de culture Résultats pour la production d'agrumes tropicaux.

Résumé -- Introduction. Les typologies agricoles et les typologies des pratiques de production visent généralement la recherche de déterminants des stratégies existantes pour la gestion des cultures. Elles constituent la première étape qui permet de fixer des objectifs d'amélioration pour les systèmes de culture. Bien qu'il existe une multitude de méthodes de typologie des exploitations agricoles, peu s'intéressent spécifiquement aux pratiques des agriculteurs, et moins encore enquêtent sur les corrélations entre ces pratiques. Nous proposons ici un cadre pour analyser les déterminants des pratiques culturales; il est basé sur l'identification de combinaisons logiques et ordonnées des techniques culturales permettant d'expliquer les modalités constitutives du système de culture. Matériel et méthodes. Le cadre d'analyse a été appliqué au cas de la production d'agrumes guadeloupéens, à partir d'un échantillon représentatif de 41 producteurs. Trois étapes ont été nécessaires pour mettre en œuvre notre cadre d'analyse. Au stade 1, des combinaisons logiques et ordonnées des pratiques culturales (CPC), constitutives d'un itinéraire technique de référence (ITR), ont été identifiées par analyse d'experts. Une typologie des pratiques culturales a alors été construite sur la base de la mesure des écarts entre les pratiques culturales des agriculteurs et celles de l'ITR. Au stade 2, les performances de gestions des cultures des agriculteurs ont été évaluées en utilisant des indicateurs pertinents. Enfin, à l'étape 3, les contraintes, liées soit à l'environnement soit à la gestion agricole dans son ensemble, qui déterminent les pratiques culturales des producteurs ont été identifiées pour faire, avec des interlocuteurs concernés, des propositions pour de futures améliorations techniques. Résultats. Les séquences de gestion des cultures ont été réduites à cinq combinaisons de pratiques culturales. Un profil technique a ensuite été déterminé pour chaque producteur, avant qu'une analyse factorielle des correspondances multiples soit exécutée. Elle a identifié deux groupes de producteurs différant par leurs profils techniques. L'analyse collective de ces résultats a mis en évidence que "la gestion de l'enherbement" était une contrainte majeure dans les systèmes de culture, révélant que l'ITR était inadapté lorsque la mécanisation du verger était impossible. Discussion. La restructuration de séquences complexes de techniques culturales en cinq combinaisons logiques des techniques a permis leur comparaison à une gestion des cultures de référence. Les contraintes des systèmes de culture et les objectifs pour d'autres améliorations ont ensuite été collectivement définis par les agriculteurs et les acteurs sociaux, avec les chercheurs. Cette analyse constitue la première étape d'un processus de refonte de systèmes de culture, et ses résultats fournissent une base solide pour une approche participative.

France (Guadeloupe) / Citrus / analyse de système / système de culture / pratique culturale / désherbage / système expert / participation / agriculteur 


\section{Introduction}

The effects of agricultural practices in orchards very often exceed the scale of the plot, so it is necessary to take into account the expectations of other natural resource users (water utility companies, natural area administrators, etc.), particularly in terms of the environment [1]. In response to these concerns, the objective of the national 'Ecophyto 2018' plan ${ }^{1}$, set up by the French Ministry for Agriculture and Forestry, is to identify, design and disseminate low-pesticide production systems, so as to reduce pesticide use by $50 \%$ on French territory by 2018. This entails both reducing use of these products, and limiting the impact of those that remain essential to protect crops from parasites, weeds and diseases. This plan emphasises the necessity to "refocus and reactivate the innovation process" within a partnership between "all the research and development stakeholders”, a prerequisite for implementing innovations in farms. How should this innovation be conceived to meet these objectives? The process of designing cropping systems is now well-established, and comprises three main stages: (i) performing a diagnostic to determine the constraints and objectives of the cropping system to be improved, (ii) generating innovative cropping systems in response to this first stage, and (iii) evaluating these new cropping systems [1]. We have focused our study on the first phase, to establish this constraint framework with a view to redesigning a cropping system.

An agronomical diagnosis evaluates a cropping system in relation to a defined innovation in performance [2]. Field typologies have been conceived to analyse an agricultural system on the regional scale, based on field investigations [3]. Different methods exist to perform a typology, most of them being farm typologies [4]: they investigate characteristics and correlations on farms' structures and environment, on farmers and their practices. Such farm typol-

1 Ecophyto 2018, 2008, Available at: http:// agriculture.gouv.fr/ecophyto2018,510\#planECOPHYTO2018. ogies may be aimed at bringing out the determinants of observed constraints on cropping practices, whether external or intrinsic to the farms. On the other hand, few typology methods deal with farmers' practices only. Existing typologies of practices generally seek correlations between one practice and the farm's characteristics or the environmental constraints [5-10]. However, all farmers' practices in a cropping system are linked with one another in an inclusive strategy, and should therefore be considered as a whole, in the form of a coherent crop management [1]. How can one perform a typology considering groups of linked practices, rather than separate practices? To our knowledge, no relevant method is yet available.

We propose here to build a method for performing a typology of crop managements. Our hypothesis was that it is possible to model all different farmers' crop managements based on the comparison with a Reference Crop Management (RCM). Two steps were followed: (i) each observed practice was separately compared with its correspondent in the RCM, and a degree of deviation from the reference practice was estimated; and (ii) for each observed cropping system, correlations between the degrees of deviations of all practices were statistically investigated. The use of a RCM thus provided the necessary standard for comparative analysis. Our objective was to test whether an analysis of deviations of observed practices from a RCM's practices was able to identify the constraints of a cropping system with respect to its improvement.

The diagnosis was completed with an investigation of the performances of the resulting crop managements [2]: simple performance indicators were accordingly selected in relation to the low-pesticide issue.

Finally, the crop management typology provided a discussion support for collectively formalising the crop management's "constraint framework", the basis for the following step of the cropping system redesigning process [1]. 
This analytical framework was used at the first stage of an improvement process for citrus cropping systems in Guadeloupe (French West Indies). The citrus industry coexists alongside the archipelago's conventional export industries (sugarcane and banana). Its importance has been recognised and supported as a priority of the Guadeloupe rural development programme (PDR-FEADER $\left.{ }^{2}, 2007-2013\right)$ in order to enable this production to cover the demand of the local market, which is still mostly covered by imports. Alongside this development, however, producers must move their activity towards a reduction of inputs, in accordance with the national objectives of the 'Ecophyto 2018' plan'. These environmental concerns had been anticipated since 1998 by the citrus growing sector. In particular, cropping practices based on the principles of integrated fruit production had been disseminated by citrus producers [11] and formalised by a reference crop management [12]. However, these cropping practices were described and propagated regardless of their validation by the farmers, who nevertheless had to cover the task of implementing them. With these new national prerogatives, we considered it necessary to check whether the cropping practices applied by Guadeloupe's citrus growers ultimately corresponded to those recommended, and how any deviations observed could be explained. We applied our analytical methodology with the ultimate goal of defining a framework of constraints and improving citrus cropping systems, with a view to meeting the objectives of pesticide use reduction through suitable cropping practices.

\section{Materials and methods}

Three stages were necessary to implement our analytical framework (figure 1). Prior to starting an analysis of practices, a preliminary farm survey was conducted among the population of farmers concerned. A farm

2 Rural Development Programme - European Agricultural Fund for Rural Development.

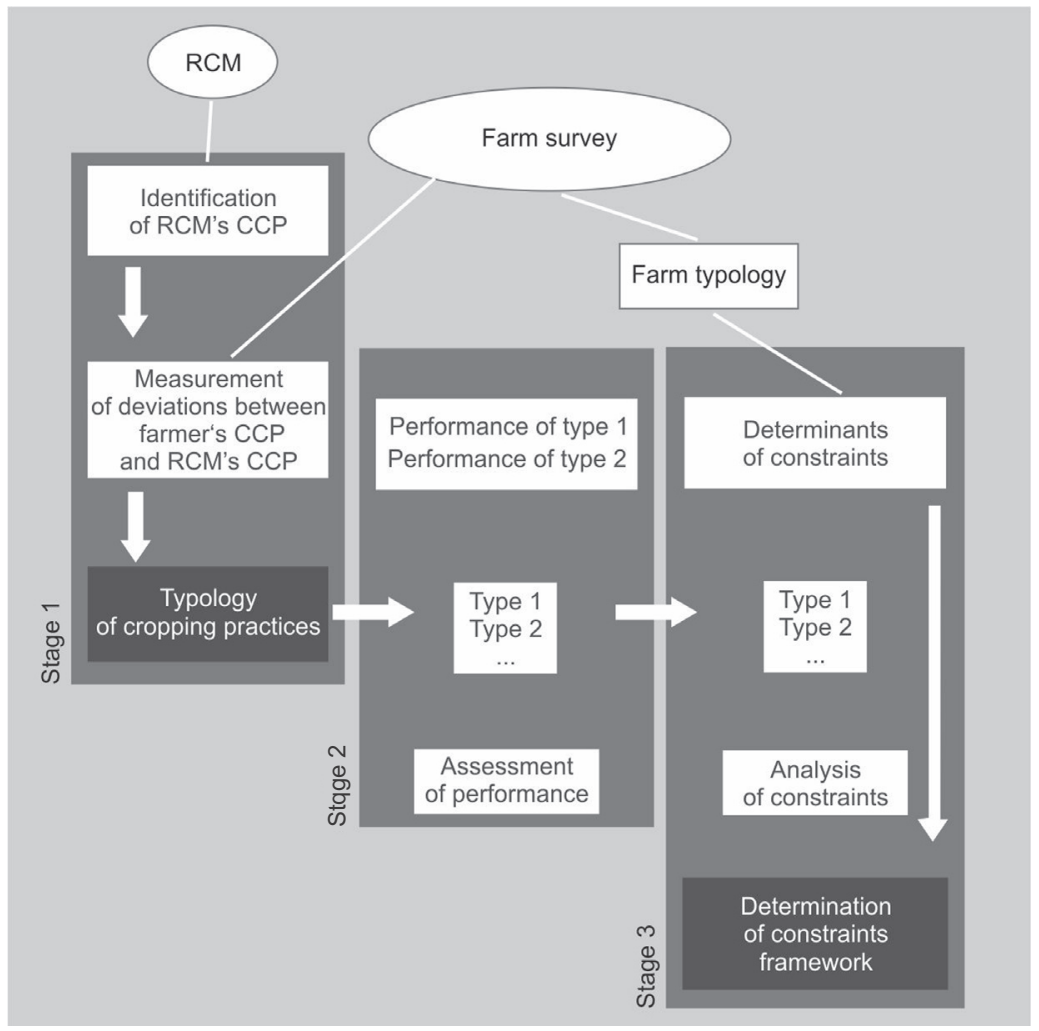

typology was built on farms' structures and strategic criteria. At stage 1, logical and ordered combinations of cropping practices (CCPs), constitutive of observed as well as reference crop managements (RCMs), were identified through expert analysis. Based on measurements of deviations between farmers' CCPs and RCMs' CCPs, a typology of cropping practices was next built. At stage 2 , the performances of farmers' crop managements were evaluated using relevant indicators. Finally, at stage 3, constraints either related to the environment or to the whole farm management - that determined producers' cropping practices were identified. The farm typology provided information for statistical interpretation of the results (figure 1: stage 1).

\subsection{Preliminary farm survey and farm typology}

A farm survey was conducted among Guadeloupe's citrus producers in 2006 [13]. It was
Figure 1.

Three stages were necessary to implement our analytical framework. Stage 1: identifying logical and ordered combinations of cropping practices (CCPs) of the reference crop management (RCM). Identifying typology of cropping practices by measurement of deviations between farmers' CCPs and the RCM's CCPs. Stage 2: using indicators to assess performance practices. Stage 3: determination of constraints. A farm typology completes the analytical framework providing information for interpreting the results from the statistical treatment. 
Table I.

The three main types of producer identified in the Beauvois farm typology [14]. 'Citrus growers' (for whom citruses represent their main activity), 'dual producers' (characterised by the co-existence of two main agricultural activities, with citruses as a secondary diversification) and 'diversified' (characterised by at least three agricultural activities, with citruses as one diversification crop among the others).

$\begin{array}{lcc}\begin{array}{l}\text { Types of producer } \\ \text { Citrus growers }\end{array} & \begin{array}{c}\text { Sumber of producers } \\ \text { (ha) }\end{array} \\ \text { Dual producers } & 11 & 60.2 \\ \text { Diversified } & 15 & 32.6 \\ & 15 & 13.2\end{array}$

based on semi-directive interviews conducted on the farm premises, and supplemented by a visit to the citrus plots. Citrus growers that owned an orchard of at least 0.5 ha (i.e., 150 to 200 trees) were interviewed. Cross-referencing of various administrative and technical databases $\left(\mathrm{DAF}^{3}\right.$, Chamber of Agriculture and CIRAD $^{4}$ ) enabled the identification of 90 citrus producers. A sub-sample of 41 producers was selected for detailed investigation, representative of the diversity of the ecological zone and the surface area criteria. In the end, the total citrus surface area of all the farms surveyed was 106 ha, i.e., 28\% of Guadeloupe's citrus growing surface area, estimated at 382 ha (General Agricultural Census, 2008). Three-quarters of the surface area planted with citruses of the surveyed sample are geographically located on the "leeward coast", the traditional zone for fruit arboriculture in Guadeloupe.

The resulting farm typology [13] was based on two main variables: the citrus surface area cultivated with citruses, and the main agricultural products (banana, sugar cane, vegetable, citrus, etc.). Three types of producers (table I) were identified, evenly distributed in the surveyed population: 'citrus growers' for whom citruses represent

\footnotetext{
3 DAF: Directorate for Agriculture and Forestry.

4 CIRAD: Centre for International Cooperation in Agricultural Research for Development.
}

their main activity; 'dual producers', characterised by the co-existence of two main agricultural activities, with citruses as a secondary diversification; and 'diversified producers', characterised by at least three agricultural activities, with citruses as one diversification crop among the others.

The farm survey covered a total of 57 variables, to be used for the following cropping practice analysis (figure 1: stage 1) then for crop management constraint analysis (figure 1: stage 3). These variables may be ordered into two groups:

- the more technical 15 variables of a first group were used to analyse the cropping techniques associated with citrus growing,

- the more structural 42 variables of a second group were used to analyse the constraints of the cropping systems; these variables related to the operator, the activities carried out on the farm, the labour employed, the equipment level, the physical description of the system studied, etc.

\subsection{Stage 1. Analytical framework of crop management: measurement of deviations between the cropping practices encountered and a reference crop management (RCM)}

First, the reference citrus crop management (RCM) [12] was synthesised (table II). Then, in order to facilitate comparisons between the observed and reference crop management, the crop operations of this RCM were reorganised into logical and ordered 
Table II.

Synthesis of the reference crop management (RCM) based on the technical recommendations propagated since 1998 among citrus producers in Guadeloupe [12].

\begin{tabular}{|c|c|c|c|}
\hline Cropping operations & Requirements & Objectives or effects sought & Examples of execution \\
\hline Planting decision & $\begin{array}{l}\text { Adhere to the ecological } \\
\text { requirements } \\
\text { of the desired crop }\end{array}$ & $\begin{array}{l}\text { Establish natural development conditions } \\
\text { for the crop }\end{array}$ & Selecting a sunny plot \\
\hline Soil analysis & Obligatory & Rectify deficits in the crop's requirements & Physico-chemical analysis \\
\hline Plot management & $\begin{array}{l}\text { Perform the operations } \\
\text { necessary } \\
\text { according to the constraints } \\
\text { encountered }\end{array}$ & Create optimum cropping conditions & $\begin{array}{l}\text { Creating a drain } \\
\text { in the case } \\
\text { of a hydromorphic zone }\end{array}$ \\
\hline Basal fertilising & $\begin{array}{l}\text { Fertilise according to the } \\
\text { recommendations } \\
\text { (soil analysis results) }\end{array}$ & Adjust fertilisation to requirements & $\begin{array}{l}\text { Input organic material } \\
\text { if measured content is too low }\end{array}$ \\
\hline Choice of trees & $\begin{array}{l}\text { Adhere to the } \\
\text { recommendations: } \\
\text { rootstock and variety }\end{array}$ & $\begin{array}{l}\text { Adhere to crop ecological } \\
\text { and technical requirements }\end{array}$ & $\begin{array}{l}\text { Use of a rootstock/variety } \\
\text { combination } \\
\text { tolerant to the tristeza virus }\end{array}$ \\
\hline Tree planting & $\begin{array}{l}\text { Adhere to the planting densities } \\
\text { according to the species, } \\
\text { variety and ecology }\end{array}$ & $\begin{array}{l}\text { Adhere to crop development } \\
\text { promoting air circulation in the plot }\end{array}$ & $\begin{array}{l}\text { For orange trees: } 5 \mathrm{~m} \times 7 \mathrm{~m} \\
\text { if altitude less than } 300 \mathrm{~m}\end{array}$ \\
\hline $\begin{array}{l}\text { Installation of irrigation } \\
\text { network }\end{array}$ & $\begin{array}{l}\text { Install a supplementary } \\
\text { irrigation system, } \\
\text { according to the ecology }\end{array}$ & Meet the crop's water requirements & $\begin{array}{l}\text { Installing an irrigation network } \\
\text { (drip system) in dry ecology }\end{array}$ \\
\hline Shape pruning & $\begin{array}{l}\text { Perform the necessary } \\
\text { shape pruning }\end{array}$ & $\begin{array}{l}\text { Promote high-quality fruit production, } \\
\text { and limit phytosanitary risks }\end{array}$ & $\begin{array}{c}\text { Pruning trees } \\
\text { to the desired shape } \\
\text { based on } 4 \text { master branches }\end{array}$ \\
\hline Regular pruning & $\begin{array}{c}\text { Perform regular pruning } \\
\text { every year }\end{array}$ & $\begin{array}{l}\text { Promote high-quality fruit production, } \\
\text { and limit phytosanitary risks }\end{array}$ & $\begin{array}{c}\text { Eliminating low branches } \\
\text { on the tree }\end{array}$ \\
\hline Fertilisation & $\begin{array}{l}\text { Apply the recommended doses } \\
\text { according to tree age, } \\
\text { split the inputs }\end{array}$ & $\begin{array}{l}\text { Meet the crop's requirements } \\
\text { and limit risks of fertiliser leaching }\end{array}$ & $\begin{array}{l}\text { Input the annual recommended } \\
\text { dose in } 4 \text { goes }\end{array}$ \\
\hline Irrigation & $\begin{array}{l}\text { Apply the recommended doses } \\
\text { according to tree age }\end{array}$ & $\begin{array}{l}\text { Meet the crop's requirements } \\
\text { to prevent excessive stresses }\end{array}$ & Spraying in dry season \\
\hline $\begin{array}{l}\text { Phytosanitary } \\
\text { treatments }\end{array}$ & $\begin{array}{l}\text { Treat if necessary after monthly } \\
\text { phytosanitary monitoring }\end{array}$ & Limit and rationalise pesticide use & $\begin{array}{l}\text { Applying anti-mealybug } \\
\text { treatment } \\
\text { if } 5 \% \text { presence threshold } \\
\text { on sample is exceeded }\end{array}$ \\
\hline Weeding & Weed under the tree foliage & $\begin{array}{l}\text { Limit competition for water } \\
\text { and fertilising elements } \\
\text { between the tree and weeds } \\
\text { Maintain perennial plant coverage } \\
\text { between the rows to limit erosion }\end{array}$ & $\begin{array}{l}\text { Manual or chemical weeding } \\
\text { located under the tree }\end{array}$ \\
\hline Harvest & $\begin{array}{l}\text { Harvest at right stage of } \\
\text { maturity, } \\
\text { size and sort the harvest }\end{array}$ & Promote production of high-quality fruits & Harvests split over time \\
\hline
\end{tabular}

combinations of cropping practices (CCPs). The aggregation process was based on expert advice and on bibliographic cross- referencing [14-17]. For each CCP, it was estimated whether an observed crop management complied or not with the reference. 
A set of binary decision-making rules (observed/ not observed) or more complex decision-making rules (using a decision tree) was used to evaluate the compliance of observed crop managements' CCPs with the RCM. For each variable in a CCP, the observed practice scored 1 if it complied with the reference, and 0 otherwise. Hence each producer was attributed a five-score profile reflecting the extent of their observance of the RCM.

Setting the CCP's deviations from the reference as bi-modal variables for analysis, a multiple correspondence factorial analysis (MCFA) was performed (using the software $\mathrm{R}^{\complement 5}$ and the 'Ade4' specific factorial analyses library). Logical links among CCPs were thus outlined.

\subsection{Stage 2. Evaluation of crop management performances}

Two levels of performance were expected from citrus crop managements: on the one hand, to secure high yields and quality of fruit, and on the other hand, to achieve the national objectives for reducing use of pesticides ('Ecophyto 2018' plan $^{1}$ ). Two indicators were selected accordingly: one to evaluate tree health (a guarantee of tree profitability) and another to evaluate the level of pesticide use.

\subsubsection{An indicator for evaluating the state of tree health}

The indicator $\mathrm{I}_{\text {Health }}$ used rated an orchard's trees' health on a qualitative scale from 0 to 1: 0 for dying or dead trees; 0.2 for neglected trees in a poor sanitary state; 0.4 for trees in a poor sanitary state, but receiving appropriate treatments; 0.6 for partly neglected trees in an average sanitary state and nonetheless bearing marketable fruits; 0.8 for trees in a satisfactory state, with some minor phytosanitary problems; 1 for trees in a highly satisfactory state. This

5 Anon., R: A language and environment for statistical computing, R Dev. Core Team, R Found. Stat. Comput., Vienna, Austria, 2008, http://www.R-project.org. assessment was performed by the surveyor during the plot visits.

\subsubsection{A treatment frequency index for evaluating the level of pesticide use}

A treatment frequency index (TFI) was adopted according to the recommendation of the 'Ecophyto 2018' plan'. It was calculated as follows: $\mathrm{TFI}=\Sigma\left[\left(\mathrm{DA} \times \mathrm{S}^{2}\right.\right.$ treated $) /$ $\left(\mathrm{DH} \times \mathrm{S}^{2}\right.$ plot)], where $\mathrm{DA}$ is the "dose applied" to the plot, $\mathrm{DH}$ the minimum approved dose per ha, and $S^{2}$ the treated and total surface areas of the plot.

A TFI for herbicides $\left(\mathrm{TFI}_{\text {herbicides }}\right)$ was calculated separately from the TFI for other phytosanitary treatments $\left(\mathrm{TFI}_{\text {treatments }}\right)$ so as to facilitate the following crop practice analyses.

\subsubsection{Analysis of correlated crop practice performances}

Relationships between the indicators' results and the observed deviations from combinations of cropping practices (CCP) were sought for using $\chi^{2}$ tests (software $\mathrm{R}^{\circledR 5}$ ). Correlations with the indicators' results were tested first for each CCP, then for grouped CCPs.

\subsection{Stage 3. Collectively building the constraint framework}

\subsubsection{Statistically analysing the crop management constraints}

Relationships between the second group of variables from the survey (see 2.1.) and the performance indicators (see 2.3.) or the observed deviations from CCPs (see 2.2.) were sought for using statistical tests for non-parametric data, i.e., $\chi^{2}$ and KruskallWallis tests, using the software $\mathrm{R}^{\circledR 5}$. The correlations found pointed out determinants of cropping practices, and hence the crop management constraints.

\subsubsection{Collective proposals for cropping system improvement}

Based on the constraint analysis of the cropping systems, we determined their main limiting factors [2]. The results were fed back to the surveyed producers (20 of whom 
attended the report meeting) [18] for validation. Once validated, the results of the analysis provided a discussion support for two different groups of stakeholders - a group of public stakeholders and a group of professional stakeholders - who decided on the improvements that were to be made to the current cropping systems. Our aim in involving the stakeholders was to create a dynamic group that would in the long term facilitate the adoption of new practices [6].

The group of public stakeholders comprised six representatives of the citrus growing sector: a producer, a researcher, a consumer, a representative of professional training, a representative of the agriculture and forestry services (DAF) and a natural area administrator from the Guadeloupe National Park. This group studied and ranked the system constraints, and co-opted two new stakeholders (one representative of a cooperative marketing structure, and one representative of the health professions) to supplement its representativeness. The ensuing discussions defined the priorities to be assigned to improving the cropping systems in order to reduce pesticide use and define its evaluation indicators.

These conclusions were used as a leadin for the second group, the so-called professional stakeholders, comprising six other people: three citrus producers, representing the three main types of producers defined by the Beauvois typology [14], one technician from an agricultural support structure and two researchers. Based on a formalised constraint framework, improvements were discussed with these professional stakeholders, with a view to redesigning the cropping systems step by step.

\section{Results}

\subsection{Stage 1. Analytical framework of crop management}

\subsubsection{Defining and comparing observed CCPs with the RCM}

Based on the Reference Crop Management (RCM) synthesis (table II), five Combinations of Cropping Practices (CCPs) were identified as coherent sets of practices essential for sound citrus orchard management (table III).

- "Cropping conditions" reflected the level of land management required for each cropping zone. Dry and wet ecological zones were considered separately.

- "Population management" considered the planting densities and their suitability for the species, variety and rootstock planted, and the plantation's altitude. It evaluates, for a given agro-ecological zone, the potential production of the plant population within a plantation. Here, altitude is a key variable, since the cropping zone is characterised by a significant altitude variation $[(0$ to 500$) \mathrm{m})$ due to its location on the slopes of the Soufrière Volcano massif.

- "Tree management" considered two main cropping operations: tree pruning and fertilisation. This CCP evaluated the supply of fertilisers throughout the orchard's lifetime, as well as the optimisation of allocation of assimilates to the reproductive part (role of pruning).

- "Weed management" considered the methods of managing invasive weeds. This CCP is focused on limiting competition between weeds and the trees.

- "Phytosanitary management" considered the relevance of phytosanitary products used according to their targets.

Binary rules or decision trees were used to evaluate the compliance of each observed CCP with the corresponding reference CCP. The general philosophy guiding this evaluation was that of rational agriculture: optimising population growth conditions according to the agro-ecological zones, and making rational use of phytopharmaceutical products (treatment with the right product, at the right dose, at the right moment).

With regard to the "cropping conditions", the orchards studied were all located in a wet tropical climate, while enjoying the Foehn effect of the leeward coast; hence, they must withstand alternating periods of heavy precipitation and periods of water shortage. Therefore, compliance with the RCM for this CCP gives priority to water supply optimisation: removal of potential 


\section{F. Le Bellec et al.}

\section{Table III.}

Simplification of reference crop management into five logical and ordered combinations of cropping practices. A simple set of decision-making rules (compliant/non-compliant) or a more complex set of rules (decision tree, figures 2 to 4 ) is used to analyse whether the combinations of cropping practices comply with the reference crop management (citrus orchards, Guadeloupe, FWI).

\begin{tabular}{|c|c|c|c|}
\hline $\begin{array}{l}\text { Combinations of cropping practices } \\
\text { derived from aggregation } \\
\text { of the reference crop management }\end{array}$ & $\begin{array}{c}\text { Aggregated cropping operations } \\
\text { of the reference crop } \\
\text { management } \\
\text { (table II) }\end{array}$ & Survey data considered & $\begin{array}{l}\text { Decision-making rules } \\
\text { for compliance analysis } \\
\text { of combinations of } \\
\text { cropping practices }\end{array}$ \\
\hline 1. Cropping conditions & $\begin{array}{l}\text { 'Planting decision', } \\
\text { 'Plot management', } \\
\text { 'Installation of irrigation network' } \\
\text { and 'Irrigation' }\end{array}$ & $\begin{array}{c}\text { Agro-ecological zone, } \\
\text { drainage, } \\
\text { topography and irrigation }\end{array}$ & Decision trees: (figures 2, 3) \\
\hline 2. Population management & $\begin{array}{l}\text { 'Choice of trees' } \\
\text { and 'Tree planting' }\end{array}$ & $\begin{array}{l}\text { Agro-ecological zone, density, } \\
\text { variety and rootstock }\end{array}$ & Observed / not observed \\
\hline 3. Tree management & $\begin{array}{l}\text { 'Shape pruning } \\
\text { and regular pruning', } \\
\text { 'Basal fertilising' } \\
\text { and 'Fertilisation' }\end{array}$ & $\begin{array}{l}\text { Pruning (shape and regular), } \\
\text { soil analysis, fertilisers } \\
\text { and splitting of fertilisation }\end{array}$ & $\begin{array}{l}\text { Observed / not observed } \\
\text { Decision tree: (figure 4) }\end{array}$ \\
\hline 4. Weed management & 'Weeding' & Weed management & Observed / not observed \\
\hline 5. Phytosanitary management & 'Phytosanitary treatments' & $\begin{array}{l}\text { Phytosanitary damage and } \\
\text { products used }\end{array}$ & Observed / not observed \\
\hline
\end{tabular}

\section{Figure 2.}

Decision tree built following expert advice to determine whether the "cropping conditions" combination of cropping practices is observed or not observed in the case of a plot located in a wet ecological zone.

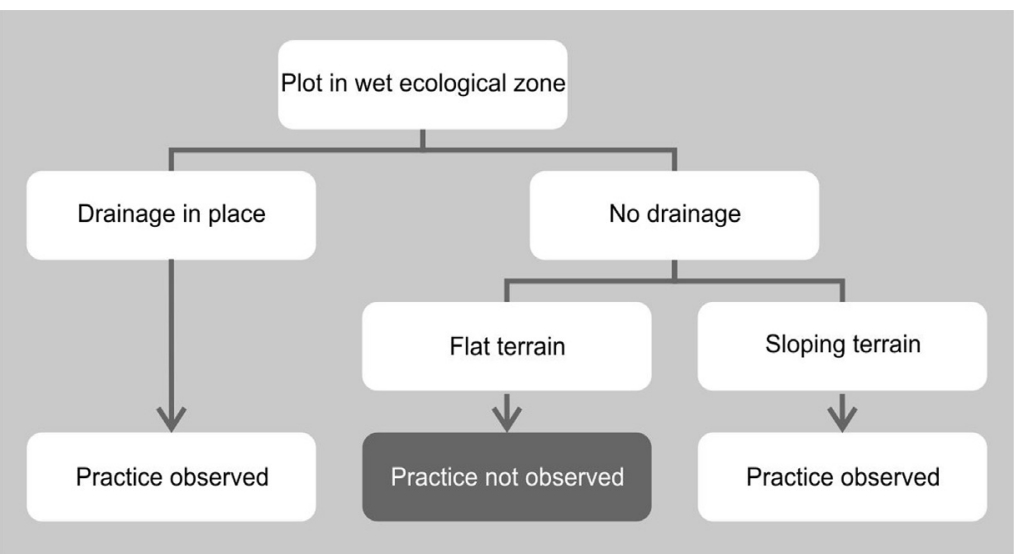

excess water by drainage and control of water input by irrigation to compensate for water shortages in periods of drought. Hence, the decision trees were built taking into account the conditions relating to the cropping zone, drainage, topography and irrigation of the orchard (figures 2, 3).

The compliance of "population management" was evaluated using a binary decision rule: failure to observe at least one of the recommendations in terms of density, species composition, variety or rootstock, according to the plantation's altitude, was regarded as non-compliance for this CCP. It was considered that the absence of just one of the conditions was enough to prevent the citrus population from achieving optimum production for its cropping zone.

The combination of "tree management" practices was evaluated separately for the fertilisation and the tree pruning variables. Compliance with the reference for the fertilisation variable was assessed based on a decision tree (figure 4): quantitatively (presence of basal fertilising and regular fertilising), and by a principle of availability over time (input of organic fertiliser mineralising over time, or split inputs). For tree pruning aspects, a binary rule (observed / not observed) was applied. Finally, the 

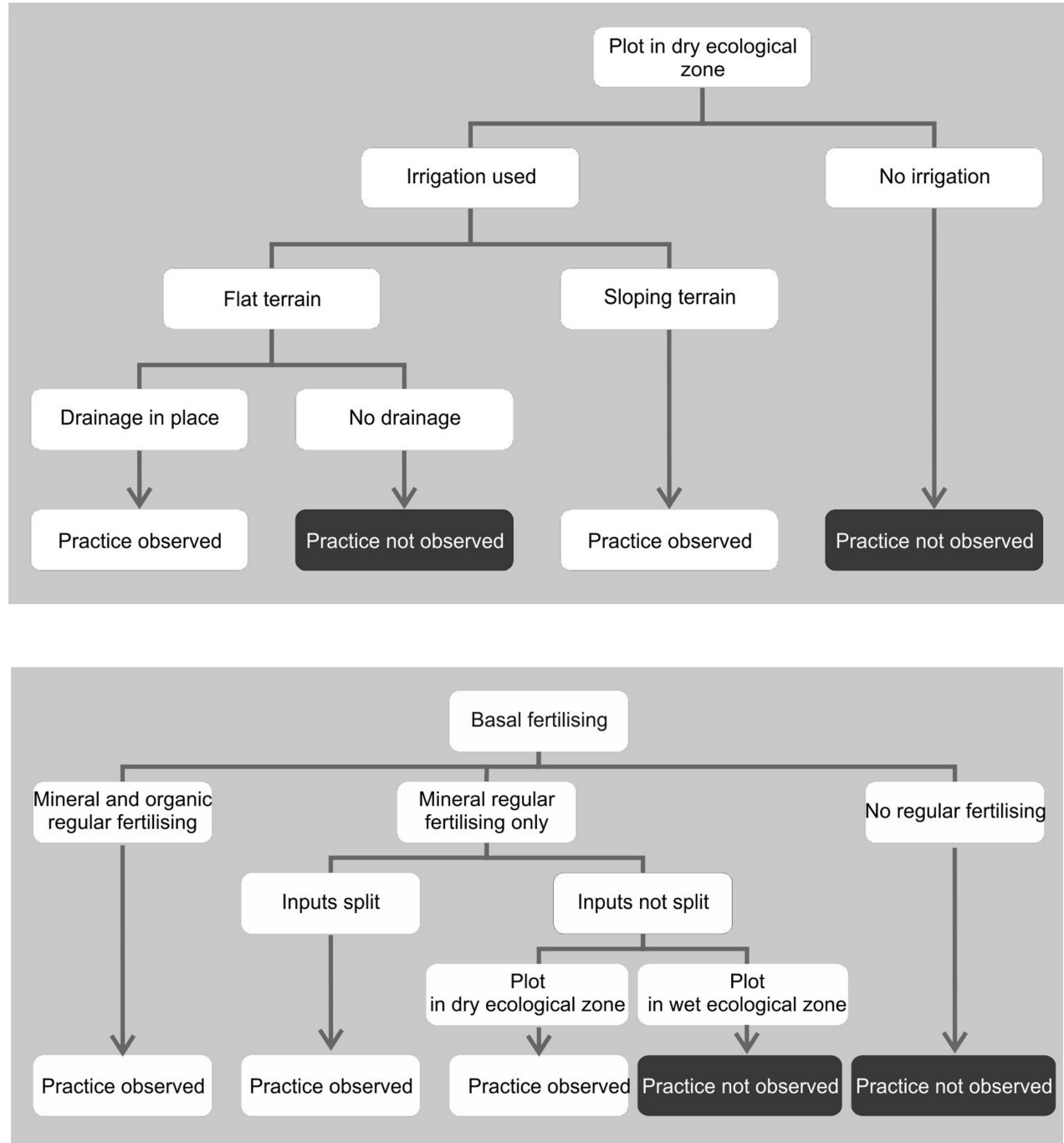

combination of "tree management" practices was deemed compliant if both cropping practices (tree pruning and fertilisation) were found to comply with the RCM.

The combination of "weed management" practices was evaluated by a binary rule (observed / not observed). In this case, the priority was to limit competition for water and fertilising elements between the trees and weeds. Consequently, localised weeding (whether chemical or manual) under the tree was deemed obligatory, and the potentially negative impact on the environment of a use of herbicide was not taken into account. Hence, three types of management complied with the RCM rules: mechanical management (mowing); manual management; and mixed management with mechanical weeding between the rows, and chemical weeding along the row or around the trees. These three practices could be used alone or in alternation.

Finally, "phytosanitary management" was graded as observed if the producer provided a suitable technical solution for the type of phytosanitary damage encountered. Hence, this method was also evaluated by a simple decision-making rule (observed/ not observed). Therefore, the priority for evaluation was given to management of phytosanitary products used by the farmer, and not directly to the environmental impact of
Figure 3.

Decision tree built following expert advice to determine whether the "cropping conditions" combination of cropping practices is observed or not observed in the case of a plot located in an ecological zone with a marked dry season.

\section{Figure 4.}

Decision tree built following expert advice to determine whether the fertilisation component of the "tree management" combination of cropping practices is observed. If basal fertilising was not applied, we deemed that the reference crop management was not observed. 


\begin{tabular}{|c|c|}
\hline Combinations of cropping practices & $\begin{array}{l}\text { Number of combinations of cropping practices } \\
\text { adhered to by all producers } \\
\text { (\%) }\end{array}$ \\
\hline Cropping conditions & 51.2 \\
\hline Population management & 63.4 \\
\hline Tree management & 43.9 \\
\hline Weed management & 58.5 \\
\hline Phytosanitary management & 39.0 \\
\hline
\end{tabular}

practices, considering only the types, doses and frequencies of the products used, and hence the evaluation factors in the correct use of the products, rather than their environmental impact.

\subsubsection{Deviation from the reference crop management as the basis for a typology of crop management}

According to our survey, observance of the combination of cropping practices (CCPs) by the producers surveyed varied from 39\% for the "phytosanitary management" aspect to $63 \%$ for "population management", while it proved that the other CCPs were followed in just one out of two cases on average (table IV). The multiple correspondence factorial analysis (MFCA) revealed links among the five identified CCPs. Axes 1 and 2 (figure 5) explained $52 \%$ of this representation.

On the representation of the MFCA (figure 5), axis 1 may be qualified as an "investment" axis. Two CCPs ("cropping conditions" and "population management") alone contribute to nearly $70 \%$ of the construction of this axis. These CCPs represent the investment made by the producers in their plantation, such as installing irrigation or drainage networks, but also the observance of planting distances. For axis 2, "weed management" alone explains nearly $50 \%$ of the axis.

This type of analysis logically contrasts the 'observed' or 'not observed' characteristics of a practice. It was found that the 'observed' characteristics of four out of the five combinations of practices were grouped together, and therefore contrasted with their 'non-observed' characteristics (figure 5): these were cropping practices directly relating to citrus cropping ("cropping conditions", "population management", "tree management" and "phytosanitary management”). The 'observed' or 'non-observed' characteristics of "weed management", however, proved to be inverted (figure 5). That is to say, producers who most observed the citrus cropping practices appeared to least observe "weed management" and vice versa.

By considering "weed management" separately from the other CCPs, we formed two groups of producers - those who observed at least three out of the four CCPs (group A), and those who observed fewer than three CCPs (group B) (figure O). The profile of the CCP followed by these two groups was illustrated graphically (figure 7). The diagram obtained enabled us to represent the contrasts of CCPs for these groups.

If we exclude "weed management", the adoption of the RCM by the group A producers varied from $71 \%$ ("phytosanitary management") to $100 \%$ ("cropping conditions"). However, for group A, "weed management" was observed in fewer than one out of two cases (42\%), which contrasts it with group B, for which this practice was better observed (67\%). In total, group A comprised 14 producers who answered our 


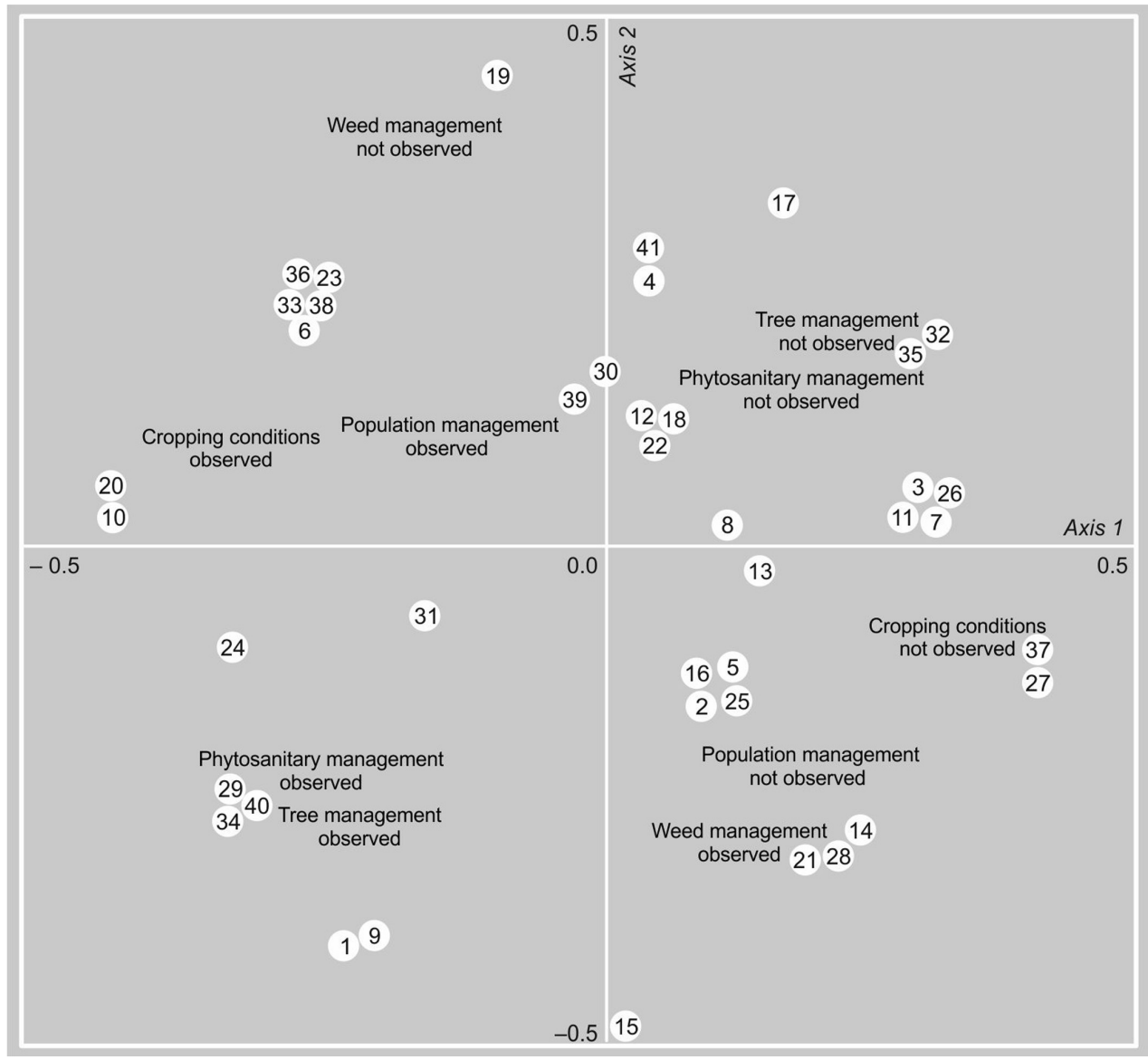

survey (representing $62 \mathrm{ha}$ ), while 27 producers (44 ha) came under group B.

\subsection{Stage 2. Evaluation of cropping practice performances}

\subsubsection{Impacts of cropping practices on tree health}

Considered individually, none of the five combinations of cropping practices (RCM) revealed an influence on tree health. However, we observed a positive influence on this indicator when at least three out of four CCPs (excluding "weed management") of the RCM were observed ( $\mathrm{I}_{\text {health }} \geq 0.8$, $p=0.005)$. This verified the performance of the RCM in terms of tree health.

\subsubsection{Impacts of cropping practices on pesticide use}

The group A producers applied treatments more often $\left(\mathrm{TFI}_{\text {treatments }}=3.42 \pm 2.82\right)$ than the group $\mathrm{B}$ producers $\left(\mathrm{TFI}_{\text {treatments }}=\right.$ $2.25 \pm 1.91 ; \quad p=0.050)$, with an average $\mathrm{TFI}_{\text {treatments }}$ of $2.65 \pm 2.29$. There was no significant difference between the two groups for $\mathrm{TFI}_{\text {herbicides. }}$. The average $\mathrm{TFI}_{\text {herbicides }}$ was $2.19 \pm 1.71$. It varied from 0 to 3 between each farm. Furthermore, the annual authorised dose of the main active ingredient used, glyphosate at $2880 \mathrm{~g} \cdot \mathrm{ha}^{-1} \cdot \mathrm{year}^{-1}$ [19], was not observed by nearly $2 / 3$ of producers. In order to observe this regulation, the TFI value for glyphosate should be less than 1.33 These quantities of herbicides applied do not

\section{Figure 5.}

Graphic representation of the multiple correspondence factorial analysis. The individuals ( 41 surveyed producers) are represented by numbers, and the observed or not observed combinations of practices are noted. The observed combinations of cropping practices contrasted with the non-observed combinations on axis 1, except for "weed management", which proved to be inverted on this same axis. "Weed management" contributed to more than $50 \%$ of the construction of axis 2 . 


\section{Figure 6.}

Three-dimensional representation of the multiple correspondence factorial analysis. Projection of individuals ( 41 surveyed producers); group A: producers observing at least three out of four combinations of cropping practices (excluding "weed management"); group B: producers observing fewer than three out of four combinations of cropping practices (excluding "weed management"). The individuals are not all visible, since some profiles are perfectly superimposed.

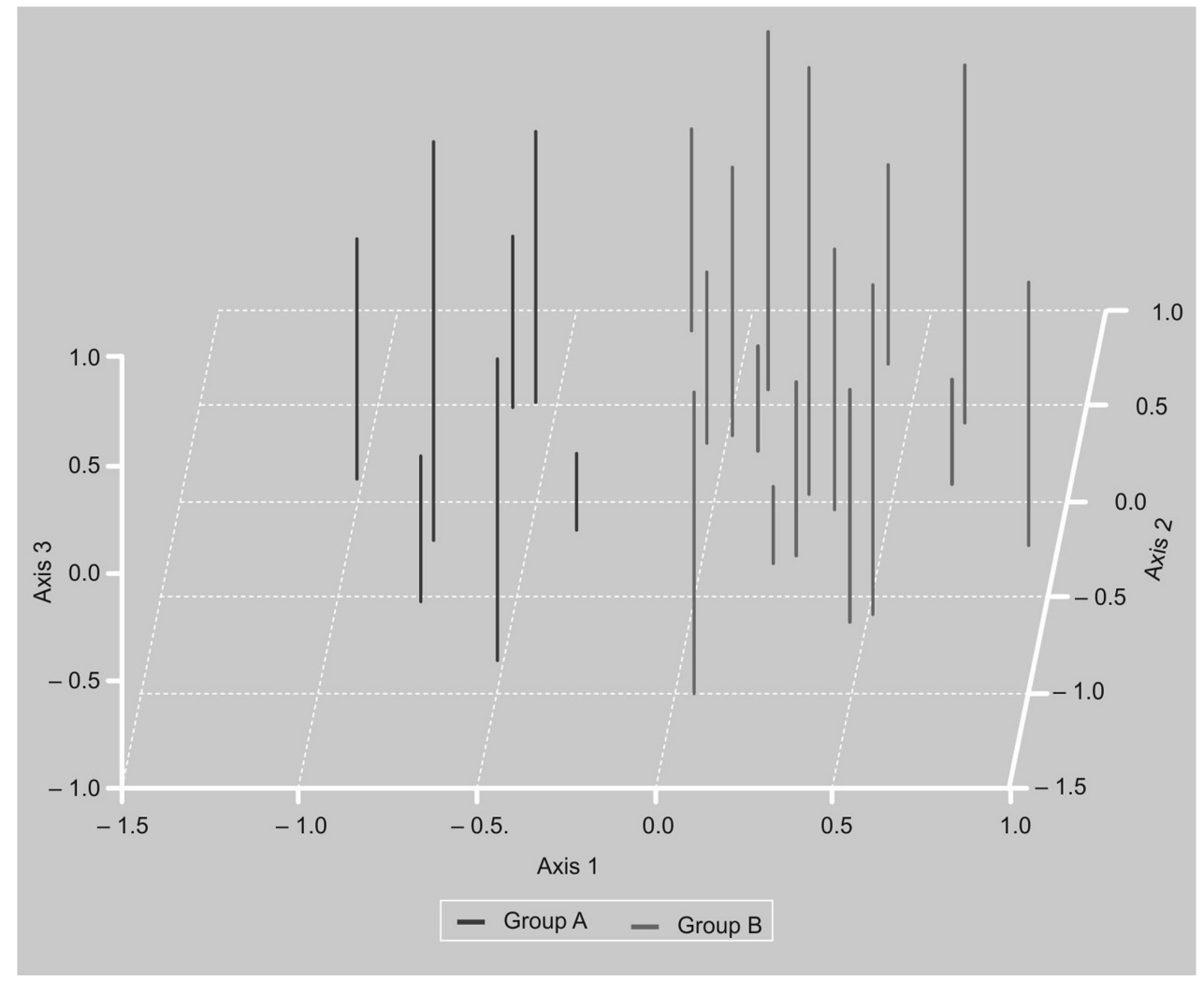

correspond to overdosing practices, but to increased frequencies of use, extended to the entire plot. The surface areas affected by this practice were high, covering $67 \%$ of the surveyed surface area.

\subsection{Stage 3. Collectively building the constraint framework}

\subsubsection{A typology to analyse the cropping system constraints}

From our survey, the appropriation of the reference crop management (RCM) for citrus by the producers appeared to be only partial, and dependent on two types of constraints.

The first type of constraint involves the lack of specific citrus growing skills and/or investment in this crop. Three main correlations between deviations from the combinations of cropping practices (CCPs) and the explanatory variables from the survey were outlined: (i) the relation between 
"phytosanitary management" and undergoing specific training in integrated fruit production was demonstrated, since this practice was better managed by trained producers $(p=0.011)$, (ii) mismatches between the active ingredient used and the target (diseases or pests) was primarily encountered in group B producers $(p=0.001)$; this could be explained by a transposition of technical knowledge from another crop (banana, vegetables, etc.) to citruses; and (iii) the importance allocated by the producers to their citrus crops played a predominant role in observance of the RCM: group A primarily comprises "citrus growers" (see table I), whose main activity is citrus cropping; there is a significant difference in affiliation between them and "dual producers" $(p=0.024)$.

The second type of constraint involves the weed management conditions. Hence, the $\mathrm{TFI}_{\text {herbicide }}$ appeared to be high if we consider the active ingredient used (glyphosate) and its regulations. It appeared that exceeding the authorised dose is not linked to overdosing practices but to a high number of applications during one year. This may be correlated with the abundance of weeds in the tropical cropping conditions, with a permanently high pressure. Another explanatory factor is the topography. The citrus plots are frequently planted on slopes $(>15-20 \%)$ with protruding rocks, where any heavy mechanisation is impossible. So it appears that mechanical weed management is difficult, which leads to the use of chemical herbicides $(p=0.0044)$. Under these conditions, "weed management" is a cropping practice subject to environmental constraints.

\subsubsection{Proposal for improvement of the cropping system, in a multi-stakeholder partnership}

The first constraint outlined by our analysis demonstrated the need for improving the phytosanitary management of the orchard (fighting parasites, including weeds). This first constraint does not call for new techniques for fighting parasites, since relevant ones are already described in the reference crop management (RCM). It seems, though, that citrus growers lack technical instruc- tions. However, the second identified constraint, the difficulty of plot mechanisation, will not be so "easily" solved. The current RCM fails to propose relevant low-herbicide weeding techniques for steep fields. Based on these conclusions, the "public stakeholders" group sorted out three improvement objectives for an innovative citrus cropping system, to be recommended in Guadeloupe: (i) reduce herbicide use in the system, (ii) develop a more eco-friendly cropping system, in particular by reducing phytosanitary treatments; both of which should also make it possible to (iii) promote high-quality fruit production to distinguish domestic citrus production from imported products. Weed management seems to be the keystone for this improvement of the cropping system, with the aim of limiting phytosanitary inputs. In line with the "professional stakeholders", the constraint framework for this improvement was drawn up, defining the objectives for designing new cropping systems (figure 8). While the advantages of rational weed management have been understood by the stakeholders (particularly in the promotion of perennial soil coverage to prevent erosion, or setting up habitat zones for beneficial arthropods), some collateral effects of these system improvement solutions have already been identified. Expected new constraints, such as higher production costs or competition for water between the cash crop and the weeds, will have to be taken into account in the following step of the redesigning process.

\section{Discussion}

The first original aspect of the agricultural diagnosis performed here was the use of a reference crop management as a basis for observed cropping practice analysis. So as to further facilitate the analysis, all agricultural practices were condensed into only five combinations of coherent cropping practices, while simple decision-making rules such as "IF condition, THEN decision" were used to attribute a specific cropping practice profile to every producer. Coupled with two relevant evaluation indicators, 


\section{F. Le Bellec et al.}

Figure 8.

Constraint framework for citrus cropping system improvement in Guadeloupe. From the constraint framework (and its consequences), we deduced with the stakeholders the ideal objectives of orchard weed management, and then the improvement objectives for the cropping system.

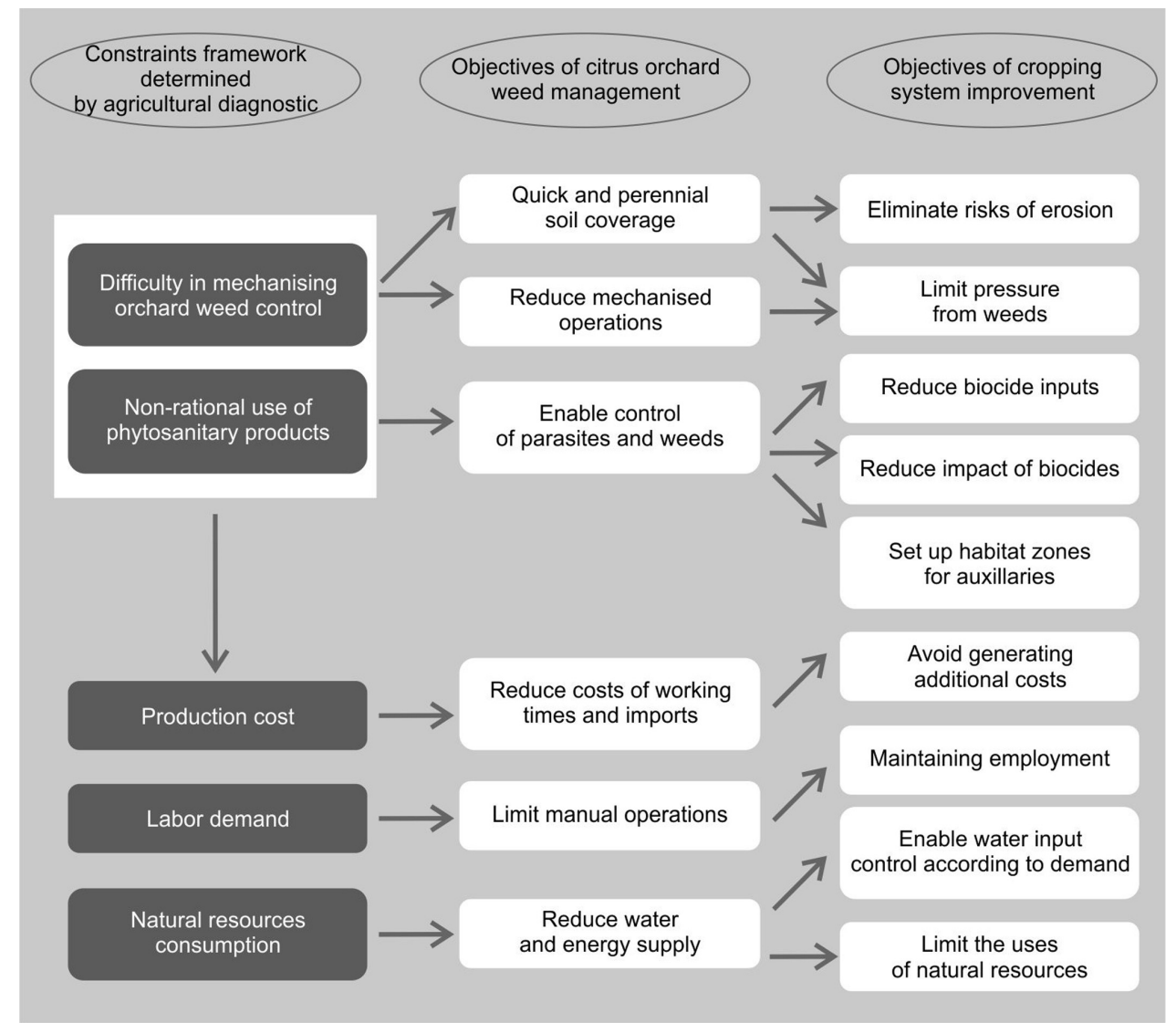

these standardised practice profiles were efficiently submitted to a statistical analysis that enabled identification of the constraints of the citrus growing systems in Guadeloupe. This methodological approach seems to be sufficiently generic to be applied to other cropping systems, provided that the knowledge of the experts for the system in question can be rallied.

The relevance of the indicators used for facilitating the interpretation of the diagnostic was particularly important [2]. We chose to use the treatment frequency index (TFI) recommended by the French public services $^{1}$ for evaluating agricultural practices and their evolution. This index is indisputable in terms of precision in that it counts the number of active ingredient doses used, but it only reflects the intensity of use of phytosanitary treatments without taking into account the specific characteristics of each phytosanitary product, such as its behaviour in the environment, its solubility, its volatility, its ecotoxicity for the environment, etc. It also does not take into account the environment-specific vulnerability for pesticide use, which depends on pedology or hydrogeology features. The final results provided by the diagnostic will depend on the choice of evaluation indicators (answering only the questions they were asked for). Consequently, while these indicators are indeed necessary for comparing cropping systems and for making the appropriate decisions for achieving the pre-defined objectives [2022], their selection or construction, in conjunction with the stakeholders concerned, seems to be an essential task.

Our analytical framework has enabled us to identify the constraints encountered by farmers with regard to pre-determined objectives, in our case reducing pesticide use. Once these constraints have been revealed, there could subsequently be many 
ways to undertake the redesign of the cropping system. There are many examples of approaches, and the degrees of involvement of the stakeholders differ greatly from one method to another. Girard, for example, involves the stakeholders very early in his construction approach, at the diagnostic stage [23]. For our part, we chose to call in the stakeholders only after the constraintdetermining stage, but before the constraints had been ranked. Our approach enabled us to: (i) rank the various identified constraints with the public stakeholders (industry and society representatives), and determine with them the improvement objectives for the cropping system concerned, and (ii) determine a constraint framework to meet these improvement objectives with the professional stakeholders (research and development stakeholders). In our approach, the public stakeholders uphold the interests of society, as each member of which is a spokesman of the entity they represent as well as a consumer. Each of these stakeholders logically protects their interests, but in a group of this sort, none of them is predominant. Hence it is the group as a whole which, through a process of negotiations, comes up with solutions that must be shared by all. Therefore, it is essential to ensure a well-mixed group, in order to prevent decisions too centred in the field of competence of particular stakeholders.

The constraint framework determined with the professional stakeholders was then used as an initial set of specifications for developing a new trial cropping system. Discussions within our second group of more professional stakeholders (farmers, technicians and researchers) were able to harness the expert knowledge of the producers, and set it against the knowledge of the technicians and researchers. Such knowledge is often a source of innovation [24, 25]. While we tried to reach consensuses, in particular to achieve apparently realistic technical solutions, this joint construction process could curb "a more innovative innovation". The constraint framework developed then enabled us to achieve a more precise definition and ranking of the improvement objectives of the previously evaluated cropping sys- tem, in order to (i) implement agricultural practices aiming to achieve these objectives, and (ii) evaluate the degree of achievement of these objectives based on criteria pre-defined by a multi-criteria analysis, for instance. This methodology, derived from Vereijken's work [26], seems particularly well suited to redesigning cropping systems, especially via the necessary multi-disciplinary and participative approach required by this type of work. Specifically, and for our case study of citrus cropping in Guadeloupe, this step-by-step redesign methodology of a cropping system led to the construction of four weed management prototypes. In the second phase of our work, these prototypes will be studied in a field trial with a systemic approach employing decision-making rules decided in conjunction with the professional stakeholders group.

\section{Acknowledgements}

We would like to express our warm thanks to all the producers, technicians and other stakeholders of the citrus growing sector in Guadeloupe for their extensive involvement in this work. We thank Andrea Pain for her linguistic support. This work received financial support from the European Union (EAFRD - European Agricultural Fund for Rural Development), and from the French State (ODEADOM), as well as the support of the Guadeloupe Region.

\section{References}

[1] Meynard J., Doré T., Habib R., L'évaluation et la conception de systèmes de culture pour une agriculture durable, Acad. Agric. Fr. 87 (2001) 223-236.

[2] Loyce, C., Wery, J., Les outils des agronomes pour l'évaluation et la conception de systèmes de culture, in: Doré T., Le Bail M., Martin P., Ney B., Roger-Estrade J., L'Agronomie aujourd'hui, Ed. Quae, Versailles, France, 2006, pp. 77-98.

[3] Kostrowicki J., Agricultural typology concept and method, Agric. Syst. 2 (1977) 33-45. 
[4] Valbuena D., Verburg P.H., Bregt A.K., A method to define a typology for agent-based analysis in regional land-use research, Agric. Ecosyst. Environ. 128 (2008) 27-36.

[5] Knowler D., Bradshaw B., Farmers' adoption of conservation agriculture: $A$ review and synthesis of recent research, Food Policy 32 (2007) 25-48.

[6] Wei Y.P., Chen D., White R.E., Willett I.R., Edis R., Langford J., Farmers' perception of environmental degradation and their adoption of improved management practices in Alxa, China, Land Degrad. Dev. 20 (2009) 336-346.

[7] Daskalopoulou I., Petrou A., Utilising a farm typology to identify potential adopters of alternative farming activities in Greek agriculture, J. Rural Stud. 18 (2002) 95-103.

[8] Rapey H., Lifran R., Valadier A., Identifying social, economic and technical determinants of silvopastoral practices in temperate uplands: results of a survey in the Massif Central region of France, Agric. Syst. 69 (2001) 119-135.

[9] Biarnès A., Rio P., Hocheux A., Analysing the determinants of spatial distribution of weed control practices in a Languedoc vineyard catchment, Agronomie 24 (2004) 187-196.

[10] Lien G., Kumbhakar S.C., Hardaker J.B., Determinants of off-farm work and its effects on farm performance: the case of Norwegian grain farmers, Agric. Econ. (2010) 41 (6) 577786.

[11] Le Bellec F., Herzog D., Fournier P., Mauléon H., Renard-Le Bellec V., Ramassamy M., The integrated fruits production in Guadeloupe, in: 41st Annu. Meet. Carrib. Food Crop Soc., AGPAC, Guadeloupe, France, 2005, $1 \mathrm{p}$.

[12] De Roffignac L., Manuel technique Cultures fruitières en Guadeloupe, Ed. ASSOFWI, Guadeloupe, France, 2008, 54 p.

[13] Beauvois C., Élaboration d'une typologie des exploitations en production d'agrumes de Guadeloupe et étude des pratiques culturales, Univ. Paris 1 Panthéon-Sorbonne, Mém. Master 2, Paris, France, 2006, 69 p.

[14] Flint M.L., Integrated pest management for Citrus, 2nd ed., Div. Agric. Nat. Resour., Univ. Calif., U.S.A., 1991, 144 p.
[15] Grisoni M., La culture des agrumes à l'île de la Réunion, CIRAD Ed., Montpellier, France, 1993, $103 \mathrm{p}$.

[16] Davies F., Albrigo L., Citrus, CAB Int., Wallingford, U.K., 1998, 254 p.

[17] Le Bellec F., Le Bellec V., Le verger tropical cultiver les arbres fruitiers, Orphie Editions, Paris, France, 2007, pp. 7-79.

[18] Le Bellec F., Bonin M., Beauvois C., RenardLe Bellec V., Tournebize R., Briand S., Denon D., Mauléon H., Petit J.M., Les producteurs d'agrumes en Guadeloupe et leurs pratiques. L'offre de formation aux producteurs en adéquation, in: Le Bellec F., La production fruitière intégrée en Guadeloupe, CIRAD, Guadeloupe, France, 2006, 1 p.

[19] Couteux A., Lejeune V., Index phytosanitaire, ACTA Ed., Paris, France, 2008, 406 p.

[20] Mitchell G., May A., McDonald A., PICABUE: a methodological framework for the development of indicators of sustainable development, Int. J. Sust. Dev. World 2 (1995) 104-123.

[21] Giupponi C., Environmental evaluation of alternative cropping systems with impact indices of pollution, Eur. J. Agron. 8 (1998) 71-82.

[22] Nolot J., Debaeke P., Principes et outils de conception, conduite et évaluation de systèmes de culture, Cah. Agric. 12 (2003) 387400.

[23] Girard N., Catégoriser les pratiques d'agriculteurs pour reformuler un problème en partenariat. Une proposition méthodologique, Cah. Agric. 15 (2006) 261-272.

[24] Darré J.P., La recherche coactive de solutions entre agents de développement et agriculteurs, Gret-Librairie, Paris, France, 2006, $112 \mathrm{p}$.

[25] Oliver Y.M., Robertson M.J., Wong M.T.F., Integrating farmer knowledge, precision agriculture tools, and crop simulation modelling to evaluate management options for poor-performing patches in cropping fields, Europ. J. Agron. 32 (2010) 40-50.

[26] Vereijken P., A methodical way of prototyping integrated and ecological arable farming systems (I/EAFS) in interaction with pilot farms, Eur. J. Agron. 7 (1997) 235-250. 
Construcción de una tipología de las prácticas culturales mediante comparación con una referencia común: primera etapa de regeneración de un sistema de cultivo- Resultados para la producción de cítricos tropicales.

Resumen - Introducción. Las tipologías agrícolas y las tipologías de las prácticas de producción pretenden generalmente investigar los factores determinantes de las estrategias existentes, de modo a gestionar los cultivos. Constituyen la primera etapa que permite fijar objetivos de mejora para los sistemas de cultivo. A pesar de que existan muchos métodos de tipología de las explotaciones agrícolas, solo hay pocas que se interesen específicamente a las prácticas de los agricultores, y menos aún, que investiguen las correlaciones entre estas prácticas. A continuación, presentamos un cuadro para analizar los factores determinantes de prácticas culturales. Éste está basado en la identificación de combinaciones lógicas y ordenadas de técnicas culturales que permitan explicar las modalidades constitutivas del sistema de cultivo. Material y métodos. El cuadro de análisis se aplicó al caso de la producción de cítricos guadalupenses, a partir de una muestra representativa de 41 productores. Se necesitaron tres etapas para poner en marcha nuestro cuadro de análisis. En la fase 1, los análisis de expertos identificaron combinaciones lógicas y ordenadas de las prácticas culturales (CPC), que constituyen un itinerario técnico de referencia (ITR). Se construyó posteriormente una tipología de las prácticas culturales, basándose en la medida de las separaciones entre las prácticas culturales de los agricultores y las del ITR. En la fase 2, se evaluaron los rendimientos de gestiones de los cultivos de los agricultores mediante el empleo de los indicadores pertinentes. Finalmente, en la fase 3 , se identificaron los obstáculos, ligados tanto al medioambiente como a la gestión agrícola en su conjunto, y que determinan las prácticas culturales de productores, de modo a hacer propuestas para mejoras técnicas en el futuro con los interlocutores implicados. Resultados. Las secuencias de gestión de cultivos se redujeron a cinco combinaciones de prácticas culturales. Después, se determinó un perfil técnico determinó entonces para cada productor antes de que se ejecutara un análisis factorial de las correspondencias múltiples. Éste identificó dos grupos de productores diferenciados por sus perfiles técnicos. El análisis colectivo de estos resultados puso de manifiesto que "la gestión de la cubierta herbosa" era un obstáculo principal en los sistemas de cultivo, mostrando que el ITR no estaba adaptado cuando la mecanización del vergel resultaba imposible. Discusión. La reestructuración de secuencias complejas de técnicas culturales, en cinco combinaciones lógicas de las técnicas, permitió compararlas a una gestión de cultivos de referencia. Después, se definieron colectivamente los obstáculos de los sistemas de cultivo y los objetivos para otras mejoras entre agricultores y actores sociales, e investigadores. Dicho análisis constituye la primera etapa de un proceso de redefinición de sistemas de cultivo, y sus resultados proporcionan una base sólida para un acercamiento participativo.

Francia (Guadalupe) / Citrus / análisis de sistemas / sistemas de cultivo / cultivo / escarda / sistemas expertos / participación / agricultores 